\title{
Effects of E-Learning on Girls' Presence and Empowerment to Access Education
}

\author{
Hessah Al-Shaya, Princess Nourah University, Saudi Arabia \\ Afnan Oyaid, Princess Nourah University, Saudi Arabia
}

\begin{abstract}
Interaction is a pivotal pedagogical concept enjoying wide-scale attention from contemporary e-learning theorists. This study investigated the effects of e-learning environments on Saudi girls' social presence and empowerment to access education. Using the community of inquiry questionnaire, the authors measured the participants' social presence in e-learning environments and conducted a discussion for their opinions regarding such environments' capacity to promote women's access to education. The study evaluates the data of 35 participants and considers descriptive statistics. The results revealed that the female student participants from Princess Nourah Bint Abdulrahman University-affiliated secondary school enjoy high levels of interaction in delivered e-learning environments. Furthermore, there was consensus on such environments' capacity to promote women's empowerment to access education and be open to the surrounding world because of their unlimited potential to overcome time and place limits as well as their benefits in tandem with women's needs and circumstances.
\end{abstract}

\section{KEYWORDS}

Classera, Community of Inquiry Questionnaire, Interaction, Social Presence, Women's Empowerment to Access Education

\section{INTRODUCTION}

Women's empowerment is the most significant concept acknowledging women's contributions as active, indispensable elements for societal growth and development. An institution like the United Nations and other economies emphasise on promoting women's skills and abilities, develop their social relationships, and support their ability to enjoy stability and equilibrium. Many organisations have prioritised women's empowerment in their development programs and projects for example; Women's Global Empowerment Fund in 2007 was established for the women of Uganda, Centre for 
Productive Rights, Women for Women International, Saudi Vision 2030 for Women Empowerment and many more (Rossen, 2018; Topal, 2019).

In a speech at the $72^{\text {nd }}$ regular session of the United Nations General Assembly (UNGA 72) in September 2017, the female representative of Saudi Arabia confirmed the country's deep belief in women's critical role in society's power. Her words confirmed that acknowledging women's social, economic, and political empowerment; providing them with safe atmospheres and services facilitating their participation in their national duties; and ensuring they benefit from the full enjoyment of their rights would contribute to increasing development along with accomplishing the country's sustainable development Vision 2030.

Education particularly promotes women's empowerment because academic achievements enable the pursuit of women's desired, effective roles in society. Notably, information and communication technology (ICT) provides tools to empower women's access to lifelong learning, continuing education, and training resources, being a basic, indispensable mechanism fostering social and economic growth and development. Lack of access to ICT denies women and their families growth opportunities and increased income; reduces communities' skill levels and limits their productivity; and hinders competitiveness in global markets (Dlodlo, 2009).

Saudi Arabia has reiterated its commitment to women's empowerment and their social, scientific, and economic advancement. The country has facilitated access to advanced technologies, e.g., e-learning environments are widely available in public schools; thus, female students have enhanced communication and exposure to the world.

Alahmari and Kyei-Blankson (2016) explained that the Classera e-learning system, an educational network providing teachers and students with a safe learning environment suitable for all educational purposes, has been adapted to various learning environments in Saudi Arabia's K-12 schools and can be integrated into online, blended, or traditional settings to improve teaching and learning; connect students with lesson content, teachers, and peers; and connect teachers with parents. Classera integrates e-learning tools and face-to-face teaching to create teacher-led learning environments and has been implemented in blended learning at selected K-12 schools. Students can interact with delivered learning content, teachers, and peers either face-to-face or online and include most features available in learning management systems (LMSs) (e.g., online grade books, assessment tools, and e-textbooks).

Yang, Yeh, and Wong (2010) regard students' educational interaction with technology as vital because it enables teachers to monitor and follow-up on students' activities. The educational literature has repeatedly emphasised that teachers who ignore technological media interactions usually induce a negative effect, hindering learning. Sharples, Taylor, and Vavoula (2007) observed interaction as a dynamic process possibly influenced by continual interactions with others.

From Garrison and Cleveland-Innes's (2005) perspective, besides participant interaction in e-learning environments, facilitating certain types of presence in learning environments (e.g., a social, cognitive, and teaching presence) is also possible. These factors contribute to fostering e-learning experiences and maximise their significance and long-term sustainability.

Several models and conceptual frameworks in the literature have attempted to manage interaction patterns and e-learning environment activities, e.g., the community of inquiry framework (CoIF) in Garrison, Anderson, \& Archer, (2000). This significant educational model is used to measure student participation, interaction, and satisfaction levels, and student-e-learning environment interactions are considered the main influencing factors in promoting students' academic achievement, success, and learning (Akyol, Vaughan, \& Garrison, 2011; Boston et al., 2009; Garrison, Anderson, \& Archer, 2010; Ke, 2010; Shea et al., 2010a, 2011).

\section{RESEARCH QUESTIONS}

The main source contributing to the research problem is Saudi Vision 2030, with its integrated plan for the future of post-oil Saudi Arabia formally announced on April 25, 2016. This document acknowledges 
the necessity for change; the urgency to implement educational policies for change, development, and reform; and the significance of women's empowerment in Saudi Arabia in all aspects of life, including education. This study is based on significant suggestions and recommendations in studies that have highlighted the importance of using Classera in the educational process, e.g., Al-Habib (2015), Awaji (2016), Alahmari and Kyei-Blankson (2016), and Alabbasi and Al Hadyan (2017).

We have used Classera to collect a random sample of female students attending Princess Nourah Bint Abdulrahman University-affiliated secondary school (PNU-ASS), a women's university, to investigate them regarding the current research problem of fulfilling the necessity to reveal how using e-learning environments affects Saudi girls' social presence and access to education. Using Classera, the present study attempts to address the following research questions;

- To what extent do the female students of Princess Nourah Bint Abdulrahman University-affiliated secondary school (PNU-ASS) interact with e-learning environments' social presence?

- What are the students' perspectives and impression regarding the ability to use Classera to promote women's empowerment to access education?

- What is the effect of using Classera on the development of the student's interaction level with the delivered e-learning environments?

\section{Research Significance}

This study's theoretical and practical significance stems from the following ideas: neglecting women's access to ICT tools denies growth opportunities and increased income to them and their families, reduces communities' skill level and productivity and hinders a country's global competitiveness (Dlodlo, 2009). Providing additional information regarding interaction in e-learning environments may benefit researchers investigating the relevant aspects of e-learning. The Classera application downloaded to mobile devices is increasingly gaining traction among female students; supports mobile learning, and increases the significance of discussing interaction in e-learning environments as the primary focus of e-learning educational studies.

\section{Research Terminology}

This study uses the following terminology.

- Interaction: Number of reciprocal events requiring interaction between at least two objects or actions (Wagner, 1994)

- Community of inquiry (CoI): A group cooperating and interacting collaboratively to participate in purposeful and meaningful processes of dialogue and critical reflection to support the required character formation and verify the validity of their mutual understanding during learning (Garrison, Cleveland-Innes, Vaughan, \& Akyol, 2011)

- Classera: An e-learning system providing teachers and students with a safe environment to communicate, collaborate, and exchange delivered instructional content, Classera's digital applications, assigned homework, students' scores, and discussions

- Social presence: Learners' ability to feel affectively and socially connected in a certain e-learning environment (Swan et al., 2008)

\section{LITERATURE REVIEW}

\section{Girls' Education and Gender Equality}

Education is considered as a powerful tool for empowerment of women, beyond a basic human right. Educating girls has a clear multiplier effect since educated women are healthier, earn more income, 
participate in the labour market to a greater extent, and provide better education and healthcare to their children (Klugman et al., 2014; McCleary-Sills, Hanmer, Parson \& Klugman, 2015). It suggests that education's benefits transmit across generations; however, financial, social and structural barriers prevent enrolment and completion of girls' education (McCleary-Sills et al., 2015). It is observed that girls and women experience multiple barriers, based on gender, age, socioeconomic status, ethnicity, and other factors, in their equal right to quality education. Statistics suggest that out 61 million children, $53 \%$ of the girls are out of school. Moreover, the gender gap is wider in the regions where out-of-school rates are higher, and they are more likely to be excluded from primary education completely (Right to Education, 2018). According to UNESCO, despite significant progress, girls are more likely never to visit a classroom than boys, reflecting a lack of gender equality in education (UNESCO, 2019). Recent research also reveals gender inequality and underrepresentation of women in science, engineering, technology and mathematics (Stoet \& Geary, 2018).

Irrespective of modernisation and technological development around the world, the question of women education and gender inequality has remained the topmost problem in the world. Though the organisations behest the states around the world to address this question, yet the status of women education and empowerment is vulnerable in most of the developing and war-torn nations. In 2005, it was recorded that 58 million girls were not enrolled in schools, specifically in the regions of Africa and the Middle East (DFID, 2005, King \& Winthrop, 2015). The deteriorated situation of women education is not improved in the present decade. The number of females out of schools are recorded 62 million according to the findings of USAID (USAID, 2015). Moreover, the number of girls out of primary schools gradually increased from 32 to 34 million between 2015 and 2016.

Recent findings reveal that the state of the problem in Sub-Sharan region is worsened as girls are denied to attain the right of education (UNESCO, 2018). One can find that it is actually because of the social set up, which constraints girls to attend an educational institution. As revealed by Nomlomo, Vuyokazi and Farag (2012), girls are not allowed to attain education along with boys since some societies and cultures dislike co-education. According to a World Bank research, it is observed that the girl's enrolment in secondary schools is higher in those countries where female teachers' rate is high. It is unfortunate that the percentage of female teachers in most of the countries around the world is even less than 25 per cent (Global Partnership, 2019).

These facts identify that the state of gender inequality is deeply rooted in societies and coming in the way of education. The gender inequalities evidently pave the way to marginalise women in the society, and it becomes the cause of forced labour, early marriages, prostitution and gender-based and sexual violence, which ultimately restrict women access to education (Nomlomo et al., 2012). Nussbaum comes up with the point that women differ with respect to their capabilities not because women are incapable, rather unequal and unjust social and political circumstances make them incapable (cited in, Aikman, \& Rao, 2012). In view of the social-cultural constraints, researchers emphasise the need to understand the way gender inequality engendered in society and how it can be countered.

\section{Role of E-Learning and its Significance}

The age of 'high-tech' has developed new patterns to impart education and knowledge. Behrouzian, Mohammad and Nejad (2012) suggest that the information and communication technology (ICT) serve as a strong and influential tool that enhance the quality and efficacy of education. ICT has the ability to transform traditional classroom pattern of study and broaden the spectrum of knowledge. In this realm, the development of the e-learning system is a potent tool and adopted by most of the countries. The Arab world is also pursuing this trend, where censorship policies usually remained strict but realising the significance of modern educational tools and promoting e-learning programs (Mirza \& Al-Abdulkareem, 2011). The importance of e-learning further increases in countries that are subject to constant political problems and social constraints. Abdeen, as cited in work of Mirza et al. (2011), highlights concerning Palestine that e-learning allows overcoming difficult circumstances in the way of education caused by Israeli constructed wall and other political problems. 
Though it is mentioned above that e-learning is now implementing in many Middle Eastern countries; yet according to previous research that people sometimes do not prefer e-learning over conventional patterns of study (Sait et al., 2003). It is further proven in the work of Mirza et al. (2011), which highlights certain challenges on the way to e-learning implementation such as unavailability and unfamiliarity with the internet. Along with a few other hurdles, the study mentions a lack of willingness of academics in the implementation due to less adherence of people to online learning. People with a low preference towards e-learning systems claim that a student less adaptable to online learning could face difficulty in gaining online education (Taylor \& Albasri, 2014; Alsayyali, 2018). This assertion is more relevant to the case of certain under-developed and developing countries, where internet penetration is limited.

However, the significance of e-learning is undeniable as a number of researchers and scholars have listed its benefits. For instance, e-learning reduces cost, saves time, keeps a curriculum up-todate, and eliminates the time and space restriction (Foltynek, \& Motycka, 2008; Guragain, 2016). E-learning can be regarded as one of the best tools that effectively process education, countering all socio-political and cultural barriers.

\section{Impact of E-Learning on Women Empowerment}

Distance education and e-learning, in the context of gender equality and women empowerment, are considered important. A research conducted by Msoffee (2016) in Tanzania University comes up with the results that e-learning helps in empowering women and promote gender equality in a gender-segregated society. In another study, which was based in KAU University, 55 per cent growth in enrolment was observed due to an e-learning program, which included females (Aljaber, 2018).

Previous research reveals that e-learning positively impacts women in several ways. Sharma, in the context of India, elaborates that E-learning, other than providing women access to knowledge, enables them to participate in the process of communication and shares their opinions (Shokeen, 2017). The research conducted by Njaya (2015) also signifies that e-learning aims to empower Zimbabwean women by diminishing socio-cultural barriers.

The Saudi Arabian society is traditionally conservative that limits education opportunities for women. According to Aljaber, (2018), Saudi students witness a "gender-segregated educational system" and mainly rely on traditional learning rather than e-learning, thus creating the need to focus on the e-learning system in the country. It is evident that the implementation of e-learning system in Kingdom of Saudi Arabia (KSA) in certain universities has positively influenced women participation and access to higher education (Al Palhares and Mcbride, 2014; Fahad, 2010; Aliaber, 2018). It is, therefore, important to focus on e-learning environments and platforms to promote and enhance women access to education.

\section{Status Quo of Classera Implementation at Schools in Saudi Arabia}

Classera has been adopted in diverse learning environments at KSA K-12 schools; and aims to improve teaching and learning processes; helps students communicate the delivered lessons' content to teachers and peers; and facilitates teacher-parent communication.

Classera focuses on 'innovation, growth, engagement, and fun for every learner. It is recognised globally, particularly in the Middle East; its beneficiaries include educational institutions in more than 17 Middle Eastern countries. The system's most notable and essential characteristic is the ease of use. Each web page's design provides the best possible user experience and guarantees usability to all user categories (e.g., students, teachers, and parents). Classera serves all stakeholders in the educational process, offering comprehensive and integrated solutions with eight basic integrated modules: a student information system, LMS, student behaviour management system, student attendance system, social learning, distance learning (DL) or virtual classrooms, financial module, and grade book and transcript management system. 
According to the literature, Classera has had positive effects on the educational process; e.g., significantly high levels of teacher satisfaction and benefits including the ease of content delivery, facilitation of student learning, and an encouraging online environment for peer collaboration and teacher-parent communication (Alahmari and Kyei-Blankson, 2016). Awaji (2016) also concluded that using Classera positively affects students' academic achievement. Alabbasi and Al Hadyan (2017) emphasised Classera's effectiveness in promoting teachers' access to information resources, improving their teaching skills, enabling students to communicate easily with teachers, and increasing students' motivation to learn.

Classera was piloted in 12 KSA public schools during the 2014-2015 school year, and its use encompasses many other $\mathrm{K}-12$ public and private schools. This expansion was in tandem with the Saudi Ministry of Education's Ten-Year Plan (2004-2014), which strongly emphasises developing the required infrastructure for digital technology and better implementation of e-learning (Alahmari \& Kyei-Blankson, 2018).

For example, Al-Habib (2015) investigated Classera's implementation requirements and barriers at KSA private schools and demonstrated that skill requirements (i.e., efficient teachers capable of using technology) ranked first, followed by other technical, financial, and administrative requirements. Financial barriers were the most critical, followed by other technical, skill-based, and administrative barriers. Al-Amro (2015) investigated these barriers from the perspective of male and female teachers in Riyadh, the capital of the KSA, and demonstrated that infrastructure and user technical support barriers ranked first, followed by curriculum, administration, and teacher barriers.

Alahmari and Kyei-Blankson's (2016) examination of the benefits, challenges, and concerns of Classera use in KSA public K-12 schools from the teachers' perspective revealed significantly high levels of teacher satisfaction and benefits: ease of content delivery, facilitation of student learning, and an encouraging online environment for peer collaboration and teacher-parent communication.

Al-Abassi and Al-Hadian (2017) explored Classera use in schools in the southern region of the KSA from the perspectives of teachers and students. The teachers viewed Classera as helping them to provide learning resources to students easily, and that using new technologies improved their skills. The students viewed Classera as providing useful, enriching resources, helping them to retrieve information and communicate with teachers easily; increased motivation to learn through Classera' points', and allowed endless replay lessons.

Finally, Alahmari and Kyei-Blankson (2018) used an online survey in the KSA to compare the differences in public and private school teachers' experiences with respect to Classera use to explore their satisfaction levels and perceived benefits, challenges, and concerns apropos adoption and implementation in the KSA K-12 educational system. They focused on the answers to three questions: (a) Do KSA public and private schools have different experiences using Classera? (b) Do teachers' levels of satisfaction with using Classera differ in public and private schools? (c) Are there significant differences between KSA public and private school teachers' perceived benefits of using Classera?

\section{Barriers to Classera Implementation at Educational Institutions}

Al-Amro (2015), Al-Habib (2015), and Alahmari and Kyei-Blankson (2016) provided a list of possible barriers to the widespread implementation of Classera, e.g., students' low income and time lost on the computer and browsing other websites; insufficient infrastructure and difficulties maintaining and programming the Internet connection devices; inadequate funding to introduce educational technologies at schools; teachers' insufficient advanced training and professional development programs; technical difficulties regarding small-sized mobile device screens; wasting time with writing, navigation, and slow Internet connection speeds; and teachers' preoccupation with conducting several teaching and administrative tasks, hindering their use of technologies. 


\section{Interaction in E-Learning Environments}

Interaction is a pivotal educational concept recognised by contemporary e-learning and DL theorists, beginning with its correspondence-based first generation at the start of the $20^{\text {th }}$ century and down to its current fifth-generation (Taylor, 2001). Moore (1989) was first to provide a three-type taxonomy for interactions in e-learning environments, namely, student-teacher, student-student, and studentcontent, and laid the groundwork for subsequent studies to examine interaction processes and activities in e-learning environments.

Garrison et al. (2000) stated that the CoIF, a process model, provides an integrated educational framework for identifying prerequisite requirements and mechanisms for successful interaction with e-learning courses and environments (Akyol et al., 2011; Boston et al., 2009; Ke, 2010; Shea et al., 2010a, 2011;). Garrison et al. (2011) modified that model for instructional design in their book E-Learning in the $21^{\text {st }}$ Century: A Framework for Research and Practice.

Garrison et al. (2011) added that the CoIF is a comprehensive process model providing students with deep, meaningful, and constructive-collaborative learning experiences through promoting its three interdependent elements: social, cognitive, and teaching presences. Garrison et al. $(2000,2011)$ and Garrison et al. (2011) prioritised the goals of elements' interaction and integration, i.e., developing a learning community enabling members to attain the highest, deepest learning and meaningful inquiry. Particularly, the CoIF comprises three main elements with several detailed sub-elements and components: a cognitive, social, and teaching presence.

Boris and Hall (2004), Duffy (2009), and Tobias (2009) demonstrated that the CoIF is based on constructivism and that it envisions learning processes emphasising the creation of a community of cooperative learners constructing the required knowledge instead of passively receiving the knowledge delivered using traditional teaching methods (e.g., memory and recitation).

Based on the theoretical principles of CoIF, subsequent researchers have designed a validated survey to measure students' satisfaction levels with interactions in e-learning courses and environments. Examples in the literature have emphasised that such a framework already has high reliability and validity levels and can be practically employed to measure the effect of using e-learning environments from students' perspectives, e.g., Arbaugh (2007), Arbaugh et al. (2007, 2008), Ice et al. (2007), Swan et al. (2008), and Garrison et al. (2010).

The CoIF is based on the philosophy of social constructivism and various learner-centred pedagogical approaches that typically include inquiry, discovery, active learning, and problem-based learning and that emphasise developing learners' higher-order thinking skills (Swanson \& Hornsby, 2000).

Following the CoIF's emergence, the Community of Inquiry questionnaire (CoIQ), a wide-scale proposed survey instrument comprising 34 items, was designed to operationalise theoretical constructs and facilitate the statistical analysis of their main dimensions and subcomponents, revealing correlation relationships. The literature has psychometrically validated CoIQ, e.g., Arbaugh et al. (2007, 2008), Arbaugh (2008), and Ice et al. (2007).

Similarly, Annand (2011) indicated the CoIQ as among the most significant educationally validated research instruments globally that could benefit from assessing interaction levels in e-learning environments. Additionally, Garrison et al. (2011) showed the literature before 2008 as repeatedly emphasising the effectiveness and applicability of such a tool in online courses and environments.

\section{Community of Inquiry Questionnaire}

The CoIQ official website (https://coi.athabascau.ca/coi-model/coi-survey) provides the following background information. The CoIQ was developed and validated by a collaborative research team, including eight of the most prominent contemporary faculty members in educational technology and e-learning course and program design at US universities. It is a stable instrument applicable in various studies, including large-scale, interinstitutional or cross-disciplinary studies (CoI, 2014). 
Ice et al. (2007), Arbaugh et al. (2008), and Diaz, Swan, Ice, and Kupczynski (2010) have indicated that the CoIQ is an empirically validated research instrument measuring students' teaching, social, and cognitive presence in e-learning environments, first designed by US researchers Arbaugh et al. (2007) and that it is based on basic theoretical principles and concepts from the CoIF.

Arbaugh et al. (2008) psychometrically validated the CoIQ as a research instrument, using a random sample comprising 287 undergraduate students enrolled in four higher education institutions in Canada and the US, with results indicating that the instrument is a valid, reliable, and efficient measure of social, cognitive, and social presence dimensions and providing additional support for the validity of the CoIQ framework for constructing effective online learning environments.

Arbaugh et al. (2008) added that such an instrument is an open resource under the Creative Commons license, concluding their study with a discussion of potential implications of further refinement of the CoIQ measures for future researchers, designers, administrators, and instructors.

Bogle, Cook, Day, and Swan (2009) concluded that since introduction in 2000, the CoIQ and its validated survey had been quoted in more than 1,000 educational studies or peer-reviewed journal articles in the field of e-learning. According to Garrison et al. (2011), the CoIQ has demonstrated high levels of reliability and validity, expanding its possible use to higher education institutions. Finally, educational researchers have further validated the CoIQ survey, e.g., Swan et al. (2008), who validated a measurement tool of presence in online communities, and Olpak and Çakmak (2018), who examined the reliability and validity of a Turkish version of the CoIQ.

This study attempted to contribute to the literature on the social presence of, and access to education for, girls in Saudi Arabia.

\section{Women's Empowerment to Access Education}

To successfully promote productivity, knowledge, and the goals of economic development, we identify barriers to women's benefits from e-learning. Antonio and Tuffley (2014) cited obstacles: women's insufficient leisure time because of their multiple social ties and commitments to their families (e.g., childcare) consuming much of their time and effort, as well as economic constraints associated with women's ability to afford the costs of e-learning subscriptions, Internet connections, and technological devices.

The literature has provided recommendations for avoiding barriers to e-learning and utilising its benefits. Njaya (2015) summarised that e-learning might suit working mothers' lifestyles and responsibilities by empowering their access to education. e.g., e-learning provides control over instructional content and delivery times and methods. It enables working women to continue their careers and education while not neglecting their families. Additionally, e-learning empowers working women to develop abilities and skills on-the-job, enabling them to compete for leadership positions and promotions, and e-learning expands social ties with students and experts. Consequently, e-learning broadens female learners' thinking and enables them to construct learning networks.

\section{METHODS}

This study used the following methods:

\section{Research Methodology}

The one-group quasi-experimental design was employed to answer this study's questions using a mixed (i.e., quantitative and qualitative) methodology.

\section{Research Population}

The study population comprised all secondary school female students in Riyadh, Saudi Arabia. 


\section{Research Sample}

Since the study using the Classera has not yet been done, this research is regarded as exploratory research since it is exploring a new e-learning system. For this reason, the sample size of the study is small, given the number of available female users. The sample (35 female students) was randomly selected from sophomores enrolled in PNU-ASS.

\section{Research Tools}

This research employed two tools to answer the research questions. Because the goal was to measure the participants' interaction levels, the CoIQ was used to measure and evaluate students' interaction levels in e-learning environments in twenty-first-century contexts. The CoIQ comprises 34 items scored on a 5-point Likert-scale, ranges from 'strongly disagree' (1 point) to 'strongly agree' (5 points), has three main dimensions, and measures students' interaction levels in e-learning environments based on the three-dimensional CoIF in Garrison, Anderson, and Archer (2000), and its recently modified version in Garrison et al. (2011).

For data collection, the researchers translated the questionnaire into Arabic. Translation of the instrument is important in research since it increases understanding of the participants and thus the response rate (Moradi, Sidorchuk \& Hallqvist, 2010). Since the researchers understand what questionnaire intends to measure; therefore, translation closely resembled the original instrument.

To consider social presence in e-learning environments, the CoI focuses on managing the social presence dimension (i.e., nine items) by measuring participants' perceptions of the following social presence sub-elements and components: (a) effective expression, (b) open communication, and (c) group cohesion. The researchers also used the in-depth discussion with the participants to ask questions regarding the capacity of Classera to promote women's empowerment to access education, facilitate the resolution of encountered difficulties and obstacles, and facilitate women's ability to be more open to the surrounding world.

\section{Statistical Techniques}

To analyse the survey data, the mean and standard deviations were statistically calculated for each item. To obtain the discussion session results, the main themes were classified into two sections, and each section focused on themes comprising all the relevant subitems with different formulas to provide a deeper understanding of the participants' responses and form a multidimensional perspective of the theme under discussion.

\section{Practical Implementation (Field Experimentation)}

The researchers introduced the treatments in the field after considering educational implications regarding planning for using Classera to promote participants' interaction, communication, and participation in the educational process according to the following four steps.

\section{Step I}

Participants were provided with a simple explanation and demonstration of Classera by focusing on its definitions and advantages, ensuring the activation of all students' accounts, and solving technical problems.

\section{Step II}

The participants and their teacher used Classera in several ways. The teacher posted information, hyperlinks, videos, or documents and uploaded learning material (i.e., the curriculum, assessment exercises, learning resources, references, presentation slides, assignments, images, and notifications); prepared tests, distributed students' scores, and granted student points; used tools for content delivery, collecting and delivering tasks and assignments, preparing subject evaluation schemes, providing 
deadlines, engaging students in interactive discussions, managing relevant topics, sharing of media, audio messages, preparation of polls and survey questionnaires; accessed the platform to communicate and follow-up with learners, especially at the start of the treatment to ensure they followed the correct steps and to provide adequate support; and communicated through the private messaging system with individual and groups of students to facilitate interactions and the exchange of opinions regarding cooperative team projects and other common activities without informing the remaining students.

\section{Step III}

An assessment of the treatment from the perspective of the participants to identify and correct mistakes and difficulties in future experiments were performed. The researchers asked the participants to assess their experiences and lessons learned in the delivered course. Additionally, the CoIQ was administered by using Google Forms to measure their interaction level with e-learning environments. This main factor has a positive influence on female teachers' academic achievement and academic, effective learning through the Classera educational network.

\section{Step IV}

The participants' opinions were elicited and noted for further analysis by conducting a discussion to assess their overall experiences and lessons learned in the delivered course that focused on the effects of using e-learning platforms (e.g., Classera) in supporting women's empowerment to access education.

\section{RESULTS}

The results of this study are explained based on the research questions posed as follows.

\section{Question I}

In Table 1, the overall mean of social presence was 3.61, statistically significant and emphasising that the students already perceive high interaction levels with delivered e-learning environments' social presence. This result corresponds to the literature, e.g., Garrison et al. (2000) and Garrison et al. (2011) but contradicts Annand's (2011) results: the CoIF does not explain the effect of social presence on successful interactions in e-learning environments.

The responses' means concerning the participants' estimation of their interaction level with the delivered e-learning environments' social presence ranged between 3.49 and 3.81. Item 18 (i.e., 'I felt comfortable participating in the Classera-delivered course discussions') had a mean of 3.94 and ranked first among interaction levels with e-learning environments' social presence with high interaction levels. Item 14 (i.e., 'getting to know other Classera-delivered course participants gave me a sense of belonging in the course') had a mean of 3.24. It ranked ninth and last among students' perceived high interaction levels with e-learning environments' social presence.

In Table 2, the overall social presence mean was 3.61, which is statistically significant and emphasises that PNU-ASS's students already have high self-perceived interaction and social presence levels in delivered e-learning environments. These results correspond to the literature, e.g., ClevelandInnes, Ice, Richardson, Shea, and Swan (2009), Swan and Ice (2010), and Swan, Matthews, Boles, and Day (2011).

\section{Question II}

The analysis of the discussion resulted in two basic themes that focus on the potential of Classera and effects of e-learning environments on women's access to education (Table 3).

In Table 3, the participants already have a satisfactory understanding and appreciation of the positive effects of e-learning environments on their learning because several discussed themes focused on Classera use and its effects that support their learning and interactions. The participants regarded 
Table 1. Means of Participants' Responses to Survey Items Measuring Their Interaction Level with E-Learning: Environments Social Presence (Arranged in a Descending Order)

\begin{tabular}{|c|c|c|c|c|c|}
\hline $\begin{array}{c}(1) \\
\text { Response }\end{array}$ & Rank & $\begin{array}{l}\text { Standard } \\
\text { Deviation }\end{array}$ & Mean & Item & $\begin{array}{l}\text { Serial } \\
\text { No. }\end{array}$ \\
\hline \multicolumn{6}{|c|}{ Dimension I: Affective Expression } \\
\hline Agree & 1 & 1.27 & 3.82 & $\begin{array}{c}\text { Online or Web-based communication via Classera } \\
\text { is an excellent medium } \\
\text { for social interaction. }\end{array}$ & 16 \\
\hline Agree & 2 & 1.37 & 3.41 & $\begin{array}{l}\text { I could form distinct impressions of some Classera- } \\
\text { delivered course participants. }\end{array}$ & 15 \\
\hline Neutral & 3 & 1.28 & 3.24 & $\begin{array}{c}\text { Getting to know other } \\
\text { Classera-delivered course participants gave me a } \\
\text { sense } \\
\text { of belonging in the course. }\end{array}$ & 14 \\
\hline - & & 1.24 & 3.49 & $\begin{array}{c}\text { Dimension I: Affective Expression } \\
\text { Overall mean }(*)\end{array}$ & \\
\hline \multicolumn{6}{|c|}{ Dimension II: Open Communication } \\
\hline Agree & 1 & 1.13 & 3.94 & $\begin{array}{l}\text { I felt comfortable participating } \\
\text { in the Classera-delivered } \\
\text { course discussions. }\end{array}$ & 18 \\
\hline Agree & 2 & 1.54 & 3.85 & $\begin{array}{l}\text { I felt comfortable conversing through the Classera- } \\
\text { based } \\
\text { online medium. }\end{array}$ & 17 \\
\hline Agree & 3 & 1.32 & 3.65 & $\begin{array}{l}\text { I felt comfortable interacting } \\
\text { with other Classera-delivered } \\
\text { course participants. }\end{array}$ & 19 \\
\hline - & & 1.21 & 3.81 & $\begin{array}{l}\text { Dimension II: Open Communication } \\
\text { Overall mean }(*)\end{array}$ & \\
\hline \multicolumn{6}{|c|}{ Dimension III: Group Cohesion } \\
\hline Agree & 1 & 0.95 & 3.65 & $\begin{array}{l}\text { I felt that my point of view was acknowledged by } \\
\text { other Classera-delivered course participants. }\end{array}$ & 21 \\
\hline Agree & 2 & 1.37 & 3.56 & $\begin{array}{l}\text { Classera-based online } \\
\text { discussions help me develop } \\
\text { a sense of collaboration. }\end{array}$ & 22 \\
\hline Neutral & 3 & 1.04 & 3.38 & $\begin{array}{c}\text { I felt comfortable disagreeing } \\
\text { with other Classera-delivered } \\
\text { course participants while maintaining a sense of } \\
\text { trust. }\end{array}$ & 20 \\
\hline \multicolumn{2}{|c|}{-} & 0.98 & 3.53 & \multicolumn{2}{|l|}{$\begin{array}{l}\text { Dimension III: Group Cohesion } \\
\text { Overall mean }(*)\end{array}$} \\
\hline \multicolumn{2}{|c|}{-} & 1.11 & 3.61 & \multicolumn{2}{|l|}{ Social Presence Overall Mean (*) } \\
\hline
\end{tabular}

$\left(^{*}\right)$ Mean is calculated according to a 5 -point scale

Classera as being largely in tandem with fulfilling the requirements of $21^{\text {st }}$-century learners because of its flexible, borderless education that overcomes the limits of place and time and its reliance on infinite educational resources in visual and auditory formats. These results correspond to the literature, e.g., Alahmari and Kyei-Blankson (2016).

Regarding the effect of e-learning environments on women's empowerment to access education, the participants emphasised that the internet, in general, and e-learning, in particular, substantially 
Table 2. Means of Princess Nourah Bint Abdulrahman University-ASS' Female Students' Social Presence in E-Learning Environments

\begin{tabular}{|c|c|c|c|}
\hline Rank & $\begin{array}{c}\text { Standard } \\
\text { Deviation }\end{array}$ & Mean $(*)$ & Cores/Dimensions \\
\hline- & 1.11 & 3.61 & Social Presence Overall Mean \\
\hline 3 & 0.75 & 3.34 & Triggering Event \\
\hline 1 & 0.94 & 3.75 & Exploration \\
\hline 2 & 0.76 & 3.73 & Integration \\
\hline 4 & 0.89 & 3.18 & Resolution \\
\hline
\end{tabular}

(*) Mean calculated according to a 5-point scale

Table 3. Discussion session results

\begin{tabular}{|c|c|}
\hline $\begin{array}{c}\text { Effect of E-Learning Environments } \\
\text { on Women's Empowerment } \\
\text { to Access Education }\end{array}$ & $\begin{array}{c}\text { Classera E-Learning } \\
\text { Environment Potential }\end{array}$ \\
\hline $\begin{array}{c}\text { Borderless education } \\
\text { overcoming time and place limits }\end{array}$ & $\begin{array}{c}\text { Quick access to information } \\
\text { and educational resources }\end{array}$ \\
\hline $\begin{array}{c}\text { Rich and multiple } \\
\text { educational resources }\end{array}$ & $\begin{array}{c}\text { Easy presentation and follow-up } \\
\text { of assignments and projects }\end{array}$ \\
\hline Keeping abreast of all innovations & Communication with subject instructor \\
\hline $\begin{array}{c}\text { Suitable learning for all health, } \\
\text { social, and financial circumstances }\end{array}$ & $\begin{array}{c}\text { Organisation and ordering the } \\
\text { sequence of deadlines }\end{array}$ \\
\hline $\begin{array}{c}\text { Social communication } \\
\text { and fruitful interactions with } \\
\text { learners worldwide }\end{array}$ & $\begin{array}{c}\text { Provision of significant support } \\
\text { for absent students to follow-up } \\
\text { on lessons and assignments }\end{array}$ \\
\hline $\begin{array}{c}\text { Easy access to teachers, experts, and } \\
\text { specialists worldwide }\end{array}$ & $\begin{array}{c}\text { Borderless education } \\
\text { overcoming time and place limits }\end{array}$ \\
\hline $\begin{array}{c}\text { Expansion of students' thinking } \\
\text { and openness to the world }\end{array}$ & \begin{tabular}{c} 
Twenty-first century teaching and learning \\
\hline
\end{tabular}
\end{tabular}

affect support for women's education; i.e., formally or informally, e-learning environments enable women to access infinite learning resources suitable for all types of learners (i.e., visual, auditory, and kinesthetic learning styles). Consequently, e-learning environments empower girls and women previously deprived of education to access education according to their needs and circumstances.

The participants also mentioned that e-learning environments and open educational resources have already enabled women, particularly housewives and child caretakers, and those with special needs, to access satisfactory levels of education, and the substantial effect of e-learning environments in edifying, opening up to the world and instilling ideas about multiculturalism. These results correspond to the literature, e.g., Gudhlanga, Magadza, \& Onias (2012), Alrashidi (2014), and Njaya (2015).

\section{DISCUSSION}

\section{Research Suggestions and Recommendations}

Based on this study's results, the researchers assert the following suggestions and recommendations. 
Firstly, Foster women's empowerment to access education by using e-learning environments. Njaya (2015) also emphasised that e-learning environments empower women while facilitating them to access education from remote settings. Also, e-learning environment would offer women to gain access to functional training, making them self-reliant as well as preparing them for the needs of the social system. Focusing on the e-learning environment could help the women to obtain educational aspirations towards a professional career and the community. E-learning could serve as an integral tool to facilitate the women to acquire education while overcoming the barriers and obstacles to physical education settings.

Also highlighting the significance of female students' outreach efforts by focusing on increasing openness to the world and ideas of multiculturalism such that it enables them to manage and overcome all barriers. According to the research conducted by Homavazir (2015), females' students are more inclined towards time schedules, and course material availability. However, oftentimes females are bound by location. E-learning environment would offer the women a borderless world through which they would be able to promote their ideas, innovation, and creativity to tap the unexplored markets.

Moreover, increasing focus on improving interactions when designing e-learning courses and environments. E-learning courses could be improved with the addition of visual aids and designs to enhance the motivation towards education. Also, Liaw and Huang (2013) indicated that communication activities like chat forums, emails, online conferences, and blogs could help in increasing the interactions of the e-learning program. Besides, Violante and Vezzetti (2015) accentuated that the addition of the gamification element in the e-learning course could offer the learners with an added benefit to imply the knowledge through simulation or gaming. Furthermore, the rewarding system within the games could motivate the learners in completing the module promptly. Short quizzes also improve user engagement while reinforcing the material. It is also recommended to Employ the CoIQ to measure the use effect of various e-learning environments. CoI offers a blended learning experience, which would enable the women to feel effective as well as socially connected with their peers. Stenbom (2018) highlighted that group cohesion improves the perception and motivation of the while offering them synchronised interactions through CoI. Through the creation of an engaging learning environment with the employment of CoIQ, student retention could be observed that would depict the persistence of online education. Stewart (2019) signified that the CoI survey is identified as a validated and reliable instrument which holds the potential to influence both the future researches and practices to build social communities for analysing collaborative learning. Implementations of the CoI would offer an advantage to assess the learner's characteristics and assist them in prioritising their learning based on their individual skillset.

Finally, use Classera to its greatest potential in education. In consideration of the opportunities and barriers of the implementations of Classera within the classroom settings, it is suggested that the basic needs and requirements of the technology integration should be thoroughly assessed. There is a high probability of failure due to limited knowledge about the technology-based program (Alahmari \& Kyei-Blankson, 2016). In this regard, consistent support and adequate resources are needed to be made available for the teachers. Also, teachers should pay equal attention to eradicate gender equality which could make the effectiveness of the e-learning system less beneficial and satisfactory. Therefore, training of the teachers and easy access to the internet should be made available at all times.

Additionally, In-service, in addition to pre-service concerning the teacher technology training programs are recommended to promote the effectiveness of Classera's in learning and teaching. Specifically, teachers are suggested to learn the use of the latest technology within their teaching practice (Alahmari \& Kyei-Blankson, 2016). Application of Classera within the classroom setups of Saudi Arabia is a fundamental step that needs to ensure continued success through professional development programs directed to improve the teaching efficiency. Also, Saudi administration and officials need to identify that integration of technology to fulfil and overcome the gender differences need intense planning and preparation time. In order to build an understanding to empower women with easy access to education, technology could play a substantial role (Suresh, 2011). In this context, it is 
important to identify ways to assist the teachers in offering additional rewards to girls who are willing to dedicate their time in ensuring learning through the utilisation of online learning resources. Lastly, the Saudi government should allocate more budget to promote the training, education, and women empowerment programs. Research by Nowak, Dahal, and Hossain (2016) emphasised that women education is necessary to improve the productivity and economic growth of a country. Therefore, e-learning could promote the women empowerment and provision of equal growth opportunities to excel in the practical world.

\section{Further Research}

To expand the literature on the effects of e-learning environments on girls' social presence and access to education in Saudi Arabia, we propose that related research consider the following ways to maximise the potential of e-learning environments to support women's education and fulfil their unique needs:

- Investigate the status of women's education in Saudi Arabia by using ICT;

- Measure the effect of Classera use on developing cooperative and self-directed learning skills; and

- Compare capacities of web-based educational networks to develop students' interaction levels.

Moreover, the current study is based on a limited dataset, which could be improved in future with the increase in the numbers of users of Classera.

\section{CONCLUSION}

This study aimed to identify the effect of e-learning environments on KSA girls' social presence and access to education. The results revealed that female students enjoy high levels of interaction with their peers and teachers when using Classera. The students agreed on the capacity of such environments to promote women's empowerment to access education, be open to the world, and avail the benefits aligned with women's needs and circumstances. Technology influences all aspects of society positively and has affected the opportunities for women in Saudi Arabia to learn and work.

\section{ACKNOWLEDGMENT}

This research was funded by the Deanship of Scientific Research at Princess Nourah bint Abdulrahman University through the Fast-track Research Funding Program. 


\section{REFERENCES}

Abrami, P., Bernard, R., Bures, E., Borokhovski, E., \& Tamim, R. (2011). Interaction in distance education and online learning: Using evidence and theory to improve practice. Journal of Computing in Higher Education, 23(2-3), 82-103. doi:10.1007/s12528-011-9043-X

Aikman, S., \& Rao, N. (2012). Gender equality and girls' education: Investigating frameworks, disjunctures and meanings of quality education. Theory and Research in Education, 10(3), 211-228. doi:10.1177/1477878512459391

Akyol,Z., Vaughan, N., \& Garrison, D. (2011). The impact of course duration on the development of a community of inquiry. Interactive Learning Environments, 19(3), 231-246. doi:10.1080/10494820902809147

Al-Amro, N. (2015). Obstacles to the use of e-learning management system (Classera) from the point of view of the teachers of Riyadh Private Schools in Riyadh (in Arabic) (Unpublished master's thesis). College of Education, King Saud University, Saudi Arabia.

Al-Asmari, A. M., \& Rabb Khan, M. S. (2014). E-learning in Saudi Arabia: Past, present and future. Near and Middle Eastern Journal of Research in Education, 2. Retrieved from https://www.qscience.com/doi/pdf/10.5339/ nmejre.2014.2

Al-Habib, A. (2015). Requirements for implementing the Classera eLearning Management System in the private schools in Riyadh [in Arabic]. International Specialized Educational Journal, 9(4), 49-62.

Alabbasi, D., \& Al Hadyan, S. (2017). The experience of using the Clasera Learning Management System in the southern limit from the point of view of male and female students: An exploratory study [in Arabic]. International Specialized Educational Journal, 6(2), 20-35.

Alahmari, A., \& Kyei-Blankson, L. (2016). Adopting and Implementing an E-Learning System for Teaching and Learning in Saudi Public K-12 Schools: The Benefits, Challenges, and Concerns. World Journal of Educational Research, 3(1), 11. doi:10.22158/wjer.v3n1p11

Alahmari, A., \& Kyei-Blankson, L. (2016). Adopting and implementing an e-learning system for teaching and learning in Saudi public K-12 schools: The benefits, challenges, and concerns. World Journal of Educational Research, 3.

Alahmari, A., \& Kyei-Blankson, L. (2018). Comparing teacher experiences using a learning management system in K-12 schools in Saudi Arabia. In J. Keengwe (Ed.), Handbook of Research on Pedagogical Models for Next-Generation Teaching and Learning (pp. 345-360). IGI Global. doi:10.4018/978-1-5225-3873-8.ch019

Aljaber, A. (2018). E-learning policy in Saudi Arabia: Challenges and successes. Research in Comparative and International Education, 13(1), 176-194. doi:10.1177/1745499918764147

Ally, M. (2004). Foundations of educational theory for online learning. In T. Anderson (Ed.), Theory and Practice of Online Learning (pp. 3-31). Athabasca University Press.

Alrashidi, A. (2014). E-learning in Saudi Arabia: A Review of the Literature. British Journal of Education. Society and Behavioural Science, 4(5), 656-672.

Alsayyali, N. M. (2018). Saudi Arabian Students' Attitudes Toward E-Learning in Select Pennsylvania Universities. Academic Press.

Angeli, C., Valanides, N., \& Bonk, C. J. (2003). Communication in a Web-based conferencing system: The quality of computer-mediated interactions. British Journal of Educational Technology, 34(1), 31-43. doi:10.1111/14678535.00302

Annand, D. (2011). Social presence within the Community of Inquiry Framework. International Review of Research in Open and Distance Learning, 12(5), 38-54. doi:10.19173/irrodl.v12i5.924

Antonio, A., \& Tuffley, D. (2014). The gender digital divide in developing countries. Future Internet, 6(4), 673-687. doi:10.3390/fi6040673

Arbaugh, J. B. (2007). An empirical verification of the Community of Inquiry Framework. Journal of Asynchronous Learning Networks, 11(1), 73-85. 
Arbaugh, J. B. (2008). Does the Community of Inquiry Framework predict outcomes in online MBA courses? International Review of Research in Open and Distance Learning, 9(2), 1-13. doi:10.19173/irrodl.v9i2.490

Arbaugh, J. B., Cleveland-Innes, M., Diaz, S., Garrison, D. R., Ice, P., Richardson, J. C., Shea, P., \& Swan, K. P. (2007). Community of Inquiry Framework: Validation and instrument development. Proceedings of the 13th Annual Sloan-C International Conference on Online Learning.

Arbaugh, J. B., Cleveland-Innes, M., Diaz, S. R., Garrison, D. R., Ice, P., Richardson, J. C., \& Swan, K. P. (2008). Developing a community of inquiry instrument: Testing a measure of the Community of Inquiry Framework using a multi-institutional sample. The Internet and Higher Education, 11(3/4), 133-136. doi:10.1016/j. iheduc.2008.06.003

Awaji, O. (2016). The effectiveness of the use of the learning management system Classera on the achievement of students in the first grade of secondary education in the English language in the city of Riyadh (in Arabic) (Unpublished master's thesis). College of Education, King Saud University, Saudi Arabia.

Bogle, L., Cook, V., Day, S., \& Swan, K. (2009). Blended program development: Applying the Quality Matters and Community of Inquiry Frameworks to ensure high quality design and implementation. Journal of the Research Center for Education Technology, 5(2), 51-66.

Boris, G., \& Hall, T. (2004). Critical thinking and online learning: A practical inquiry perspective in higher education. Proceedings of the 20th Annual Conference on Distance Teaching and Learning.

Boston, B., Diaz, S., Gibson, A., Ice, P., Richardson, J., \& Swan, K. (2009). An exploration of the relationship between indicators of the Community of Inquiry Framework and retention in online programs. Journal of Asynchronous Learning Networks, 13(3), 67-83.

Classera Inc. (2017). https://www.classera.com/en/home/

Cleveland-Innes, M., Ice, P., Richardson, R. C., Shea, P., \& Swan, K. P. (2009). Community of Inquiry Framework: 10 years old and going strong. Proceedings of the 15th Annual Sloan-C International Conference on Online Learning.

CoI. (2014). The Community of Inquiry. Retrieved from: https://coi.atha bascau.ca

Diaz, S. R., Swan, K., Ice, P., \& Kupczynski, L. (2010). Student ratings of the importance of survey items, multiplicative factor analysis, and the validity of the Community of Inquiry Survey. Internet and Higher Education, 13(1-2), 22-30. doi:10.1016/j.iheduc.2009.11.004

Dlodlo, N. (2009). Access to ICT education for girls and women in rural South Africa: A case study. Technology in Society, 31(2), 168-175. doi:10.1016/j.techsoc.2009.03.003

Duffy, T. M. (2009). Building lines of communication and a research agenda. In S. Tobias \& T. M. Duffy (Eds.), Constructivist Instruction: Success or Failure? (pp. 351-371). Routledge.

Fahad, N. (2010). The learners' satisfaction toward online e-learning implemented in the college of applied studies and community service, King Saud University, Saudi Arabia: Can E-learning replace the conventional system of education? The Turkish Online Journal of Distance Education, 11.

Foltynek, T., \& Motycka, A. (2008). Time management in e-learning. Faculty of business and Economics, department of Informatics. Mendel University.

Garrison, D. R., Anderson, T., \& Archer, W. (2000). Critical inquiry in a text-based environment: Computer conferencing in higher education. The Internet and Higher Education, 2(2/3), 87-105.

Garrison, D. R., Anderson, T., \& Archer, W. (2010). The first decade of the Community of Inquiry Framework: A retrospective. The Internet and Higher Education, 13(1/2), 5-9. doi:10.1016/j.iheduc.2009.10.003

Garrison, D. R., \& Arbaugh, J. B. (2007). Researching the Community of Inquiry Framework: Review, issues, and future directions. The Internet and Higher Education, 10(3), 157-172. doi:10.1016/j.heduc.2007.04.001

Garrison, D. R., \& Cleveland-Innes, M. (2005). Facilitating cognitive presence in online learning: Interaction is not enough. American Journal of Distance Education, 19(3), 133-148. doi:10.1207/s15389286ajde1903_2 
Garrison, D. R., Cleveland-Innes, M., Vaughan, N., \& Akyol, Z. (2011). Community of Inquiry Model. Retrieved from: http://communitiesofinquiry.com/model

Global Partnership Education. (2019). Explore global education statistics on challenges and results organised by theme, including specific data for GPE partner countries. Retrieved from https://www.globalpartnership. org/data-and-results/education-data

Gudhlanga, E. S., Magadza, S. N., \& Onias, M. A. F. A. (2012). Challenges and opportunities for women participating in open and distance learning at the Zimbabwe Open University: A Case of Matabeleland North and Bulawayo Regions. International Women Online Journal of Distance Education, 1(1).

Guragain, N. (2016). E-Learning Benefits and Applications. Helsinki Metropolia University of Applied Sciences. Retrieved from https://www.theseus.fi/bitstream/handle/10024/105103/Guragain_Nischal. pdf?sequence $=1 \&$ isAllowed $=y$

Homavazir, Z. F. (2015). Impact of E-learning on student learning and employability - A study in India. DY Patil University.

Ice, P., Arbaugh, J. B., Diaz, S., Garrison, D. R., Richard, J., Shea, P., \& Swan, K. (2007). Community of Inquiry Framework: Validation and instrument development. Proceedings of the 13th Annual Sloan-C International Conference on Online Learning.

Ke, F. (2010). Examining online teaching, cognitive, and social presence for adult students. Computers \& Education, 55(2), 808-820. doi:10.1016/j.compedu.2010.03.013

King, E. M., \& Winthrop, R. (2015). Today's Challenges for Girls' Education. Brooking Institute. Retrieved from https://www.brookings.edu/wp-content/uploads/2016/07/Todays-Challenges-Girls-Educationv6.pdf

Kulkarni, S. M. (2017). Women empowerment in 21st century. Proceedings of the International Conference on Liberalization, Privatisation, and Globalisation: Impact on Indian System-An Assessment.

Liaw, S. S., \& Huang, H. M. (2013). Perceived satisfaction, perceived usefulness and interactive learning environments as predictors to self-regulation in e-learning environments. Computers \& Education, 60(1), 14-24. doi:10.1016/j.compedu.2012.07.015

Mirza, A. A., \& Al-Abdulkareem, M. (2011). Models of e-learning adopted in the Middle East. Applied Computing and Informatics, 9(2), 83-93. doi:10.1016/j.aci.2011.05.001

Moore, M. G. (1989). Three types of interaction. American Journal of Distance Education, 3(2), 1-6. doi:10.1080/08923648909526659

Moradi, T., Sidorchuk, A., \& Hallqvist, J. (2010). Translation of questionnaire increases the response rate in immigrants: Filling the language gap or feeling of inclusion? Scandinavian Journal of Public Health, 38(8), 889-892. doi:10.1177/1403494810374220 PMID:20534633

Msoffe, R. M. (2016). The role of open and distance learning in gender equality and women empowerment: A case of Diploma in Primary Teacher Education. The Open University of Tanzania.

Nejad, Behrouzian, M., \& Nejad, E. (2012). Impact of E-Learning on Learning and Realising Information Society. Research Journal of Applied Sciences, Engineering and Technology, 4, 5016-5020.

Njaya, T. (2015). Women empowerment through open and distance learning in Zimbabwe. IOSR Journal of Humanities and Social Science, 20(2), 83-90.

Nomlomo, , \& Farag, , \& Holmarsdottir. (2012). Challenges to gender equality and access in education: Perspectives from South Africa and Sudan. Southern African Review of Education, 18, 41-57.

Nowak, H. A., Dahal, G., \& Hossain, I. (2016). Women Education and Empowerment: Its Impacts on Socioeconomic Development in Bangladesh and Nepal. Fourth 21st CAF Conference in Harvard.

Olpak, Y. Z., \& Çakmak, E. K. (2018). Examining the reliability and validity of a Turkish version of the Community of Inquiry Survey. Online Learning Journal, 22(1), 142-160. doi:10.24059/olj.v22i1.990

Picciano, A. (2002). Beyond student perceptions: Issues of interaction, presence, and performance in online courses. Journal of Asynchronous Learning Networks, 6, 21-40. 
Rossen, J. (2018). 15 organisations Helping Women Around the World. Retrieved from: https://www.mentalfloss. com/article/534393/organizations-helping-women-around-world

Sharma, N. K. (2015). Effects of E-Learning in Education and Women Empowerment. Academic Press.

Sharples, M., Taylor, J., \& Vavoula, G. (2007). A theory of learning for the mobile age. In R. Andrews \& C. Haythornthwaite (Eds.), The Sage Handbook of E-Learning Research (pp. 221-247). Sage Publications. doi:10.4135/9781848607859.n10

Shea, P., Gozza-Cohen, M., Uzuner, S., Mehta, R., Valtcheva, A. V., Hayes, S., \& Vickers, J. (2011). The Community of Inquiry Framework meets the SOLO Taxonomy: A process-product model of online learning. Educational Media International, 48(2), 101-113. doi:10.1080/09523987.2011.576514

Shea, P., Hayes, S., Vickers, J., Gozza-Cohen, M., Uzuner, S., Mehta, R., \& Rangan, P. (2010a). A re-examination of the Community of Inquiry Framework: Social network and content analysis. The Internet and Higher Education, 13(1/2), 10-21. doi:10.1016/j.iheduc.2009.11.002

Shokeen, D. A. (2017). Women Empowerment through Open and Distance Learning in India. Academic Press.

Stenbom, S. (2018). A systematic review of the Community of Inquiry survey. The Internet and Higher Education, 39, 22-32. doi:10.1016/j.iheduc.2018.06.001

Stewart, M. K. (2019). The Community of Inquiry Survey: An Assessment Instrument for Online Writing Courses. Computers and Composition, 52, 37-52. doi:10.1016/j.compcom.2019.01.001

Suresh, L. B. (2011). Impact of information and communication technologies on women empowerment in India. Systemics, Cybernetics and Informatics, 9(4), 17-23.

Swan, K., \& Ice, P. (2010). The Community of Inquiry Framework ten years later: Introduction to the special issue. The Internet and Higher Education, 13(1/2), 1-4. doi:10.1016/j.iheduc.2009.11.003

Swan, K., Matthews, D., Boles, E., \& Day, S. (2011). Linking Online Course Design to Learning Processes Using the Quality Matters and Community of Inquiry Frameworks. Basic Books.

Swan, K., Shea, P., Richardson, J., Ice, P., Garrison, D. R., Cleveland-Innes, M., \& Arbaugh, J. B. (2008). Validating a measurement tool of presence in online communities of inquiry. E-Mentor, 2(24), 1-12.

Swanson, K., \& Hornsby, K. (2000). A community of inquiry: A survey of traditional classroom and Web-course application. Analytic Teaching, 21(2), 87-105.

Taylor, J. C. (2001). Fifth Generation Distance Education. Retrieved from: www.usq.edu.au/users/taylorj/ conferences.htm

Tobias, S. (2009). An eclectic appraisal of the success or failure of constructivist instruction. In S. Tobias \& T. M. Duffy (Eds.), Constructivist Instruction: Success or Failure? (pp. 335-350). Routledge. doi: $10.4324 / 9780203878842$

Topal, A. (2019, September). Economic reforms and women's empowerment in Saudi Arabia. Women's Studies International Forum, 76, 102253. doi:10.1016/j.wsif.2019.102253

UNESCO. (2018). Education Data Release: One in Every Five Children, Adolescents and Youth is Out of School. Sustainable Development Goals. Retrieved from http://uis.unesco.org/en/news/education-data-release-one-everyfive-children-adolescents-and-youth-out-school

United Nations Entity for Gender Equality and the Empowerment of Women (UN Women) \& United Nations Global Compact (UNGC). (2011). Women's Empowerment Principles: Equality Means Business (2 ${ }^{\text {nd }}$ ed.). New York, NY: The Author.

USAID. (2015). Let Girls Learn. Retrieved from https://www.usaid.gov/sites/default/files/documents/1869/ USAID_LGL_FactSheet.pdf

Violante, M. G., \& Vezzetti, E. (2015). Virtual interactive e-learning application: An evaluation of student satisfaction. Computer Applications in Engineering Education, 23(1), 72-91. doi:10.1002/cae.21580

Wagner, E. D. (1994). In support of a functional definition of interaction. American Journal of Distance Education, 8(2), 6-26. doi:10.1080/08923649409526852 
Yang, Y. F., Yeh, H. C., \& Wong, W. K. (2010). The influence of social interaction on meaning construction in a virtual community. British Journal of Educational Technology, 41(2), 287-306. doi:10.1111/j.14678535.2009.00934.x

Hessah Alshaya (PhD) is a Professor of Educational Technology at Princess Nourah University in Riyadh, Saudi Arabia. Author of three books and published several papers in English and Arabic. Winner of Khalifa Award for Education 2017.

Afnan A. Oyaid $(P h D)$ is an Associate Professor of Educational Technology at Princess Nourah University in Riyadh, Saudi Arabia. Author of three books and published several papers in English and Arabic. Winner of Khalifa Award for Education 2017. 